\title{
Centralizing PERIPHERIES: THE BELT AND ROAD INITIATIVE AND ITS ROLE IN THE DEVELOPMENT OF THE CHINESE BORDERLANDS
}

\author{
ALESSANDRO RIPPA ${ }^{1}$ \\ LUDWIG MAXIMILIAN UNIVERSITY OF MUNICH
}

\begin{abstract}
Based on the analysis of two case studies, Tashkurgan in Xinjiang province and Houqiao in Yunnan province, this paper makes two connected arguments about China's Belt and Road Initiative, also known as One Belt, One Road (OBOR). First, it shows that OBOR shares many characteristics with previous projects to develop the borderlands, yet its vision differs significantly. In particular, the initiative marks a discursive shift in the official view of China's western provinces by "centralizing" the borderlands and thus favoring the branding of the initiative as "mutually beneficial" for both China and its neighboring countries. Furthermore, it shows that another reason for OBOR's current success lies in the initiative's vagueness - an asset, however, that can become one of the initiative's greatest liabilities.
\end{abstract}

Keywords: One Belt One Road, New Silk Road, Chinese borderlands, development, Yunnan, Xinjiang

\footnotetext{
${ }^{1}$ Alessandro Rippa is a postdoctoral fellow at Ludwig Maximilian University of Munich and member of the research project "Remoteness and Connectivity: Highland Asia in the World". Research for this article was conducted with the generous support of the European Research Council (Starting Grant 637764, Highland Connections). The author would like to thank Gang Chen, Carolin Maertens, and the anonymous reviewers for their insightful comments on various versions of this article.
} 


\section{Introduction}

In the fall of 2013, during two visits to Kazakhstan and Indonesia, Chinese President Xi Jinping put forward the strategic framework for the construction of the "Silk Road Economic Belt" and the "21st Century Maritime Silk Road", then collectively referred to in Chinese as "yidaiyilu"- "One Belt, One Road" (OBOR). Since then, China's newest global initiative has been widely discussed, and "One Belt, One Road" has become a somewhat familiar expression even outside the circle of socalled "China watchers". Also known as the Belt and Road Initiative, OBOR is President Xi Jinping's signature foreign policy project, and its importance for both domestic economic goals and global strategic vision cannot be overestimated. Broadly speaking, the initiative is designed to open up massive economic zones and corridors through an indefinite number of infrastructural projects across, but not necessarily limited to, Asia, as well as to establish China-centric trade and financial ties.

Many Western analysts have focused on the geopolitical implications of the Belt and Road Initiative. In particular, the initiative has been seen as threatening American interests in Asia, and openly competing with projects such as the U.S.-led New Silk Road, the Pivot to Asia, the TransPacific Partnership, and even Russia's Economic Union. The initiative, however, is rooted in China's economic transition, and particularly in its needs to integrate chronically underperforming western regions, absorb the country's industrial overcapacity, and help State-owned enterprises (SOE) by giving them new access to credit (Johnson 2016). Furthermore, as argued by Callahan (2016), OBOR, as the cornerstone of Beijing's "peripheral diplomacy" (zhoubian waijiao), aims at promoting China's new vision of global governance. The initiative, then, is part of a larger strategy which is as much about "the hard power of infrastructure" as it is concerned with "the soft power connectivity of ideas, institutions, and behavior in diplomacy itself" (Callahan 2016: 2-3).

Unlike most current literature on OBOR, this paper examines two specific case studies in order to make an argument about the vision behind the initiative. Moving from the analysis of Tashkurgan and Houqiao, in Xinjiang and Yunnan respectively - China's gateways to Central and Southeast Asia-it thus argues that OBOR shares many characteristics with previous projects to develop the borderlands, particularly the Open Up The West campaign, yet its vision differs significantly. In particular, the initiative marks a discursive shift in the official view of China's Western provinces-“centralizing" the borderlands and thus favoring the 
branding of the initiative as "mutually beneficial" for both China and its neighboring countries involved in the initiative.

In order to make this argument, the paper is organized as follows. First it describes the Open Up The West Campaign, the first program to comprehensively address the issue of the development of China's western provinces. Then the paper analyses the cases of Kashgar and Tashkurgan in Xinjiang province, and Tengchong and Houqiao in Yunnan province. This section is based on the analysis of various materials and interviews collected over periods of ethnographic research carried out in both contexts between 2009 and 2016, for a total of about two years. The last two sections discuss, respectively, the similarities and differences between OBOR and the Open Up The West Campaign, arguing that the Belt and Road Initiative marks a significant discursive shift that sets it quite apart from any previous initiative. In the conclusion, I argue that OBOR's current success is partly due to the apparent vagueness of many of its projects: a powerful tool that might also become a haunting liability.

\section{From the Open Up The West campaign to OBOR}

The "Open Up The West" (xibu da kaifa) campaign, officially launched in June 1999, was the first and most prominent government program aiming at reducing the growing social and economic divide between China's fast-developing coastal regions and the country's peripheral western regions (Lai 2002). The strategy for the campaign, also known as "Develop the West" or "Great Western Development", was initially laid out in March 1999 at the 9th National Party Congress in Beijing by former CCP General Secretary Jiang Zemin. In his own words:

The Western area is large, and comprises over the half of the whole of the state's territory. But the majority is in a state of underdevelopment or wilderness. The West [of China] must sooner or later be developed. Otherwise, how could we reach a modernization of the whole country? How could China become a strong economic state? (Yan 2001: 1).

If the main rationale behind the campaign was economic, the strategic implications of such endeavor were also central to its implementation. As Jiang Zemin put it in 1999:

The minorities are quite concentrated in the West [of China], and it is also a border area. Hastening development of the West would preserve political and social stability. Therefore promotion of national unity and safeguarding of border security is of great significance (Yan 2001: 2). 
As a strategy, the Open Up The West campaign was mostly concerned with internal development, thus most investments were initially dedicated to developing transportation, energy, communication, and improving urban infrastructure in the western regions. More specifically, "weighing its limited resources against the vastness of the underdeveloped interior, the center has chosen to target key areas (zhongdian quyu) - those with relatively firm economic bases and high population densities - close to transportation routes and hubs" (Lai 2002: 450). Consequently, although principally focused on internal development, the campaign reverberated beyond China's borders, and led to a number of initiatives aiming at enhancing cooperation between China and its border nations-very often along the same routes and hubs that the campaign targeted in the first place.

One prominent example is that of the so-called "Kunming Initiative", the result of a conference at the Yunnan Academy of Social Sciences in August 1999, in which academics and experts from China, India, Burma and Bangladesh participated to discuss the following topics:

1. Practical and strategically significance for the regional cooperation among China, India, Bangladesh and Burma;

2. Feasibility of cooperation in the economic, trade and technological cooperation among China (Yunnan), India, Bangladesh and Burma (including industry, agriculture, tourism and finance);

3. Study on the construction of communication channels and networks among China, India, Bangladesh and Burma (including the opening and reconstructing roads, air lines, water routes and railways);

4. Prospect and basis for the economic cooperation among China, India, Bangladesh and Burma;

5. Open-door policies and trade and investment environment for China, India, Bangladesh and Burma; and

6. Construct the framework for regional cooperation in China, India, Bangladesh and Burma. ${ }^{2}$

The conclusions followed a similar narrative, with a general call for the four governments to improve regional cooperation and focus on "infrastructure development in order to enhance connectivity". The conference thus laid out the framework for the Bangladesh-China-IndiaMyanmar Economic Corridor (BCIM), an initiative which has now been incorporated into the OBOR strategy, and which will be discussed in more detail below.

\footnotetext{
${ }^{2}$ Kunming Initiative: China, Burma, India \& Bangladesh: http://www.ibiblio.org/obl/reg.burma/archives/199908/msg00946.html.
} 
In Western China, similar efforts culminated in 2001 with the creation of the Shanghai Cooperation Organization (SCO) between China, Kazakhstan, Kyrgyzstan, Russia, Tajikistan, and Uzbekistan. In the "Declaration of the Shanghai Cooperation Organization", that resulted from the founding meeting of the group, the main focus was on the strategic value of the SCO and its implications for regional security. However, a general call for "multilateral cooperation" and "trade and investment facilitation" between the member states was also included. ${ }^{3}$ As has been argued by various analysts (Clarke 2008; Becquelin 2004; Shichor 2008; Laruelle and Peyrouse 2012), the political and economic integration of Xinjiang with Central Asia grants China benefits that serve two purposes: the consolidation of China's control of Xinjiang and the expansion of Chinese power in Central Asia. It thus refers to a state project of nation-building, as much as to one of economic growth and integration.

In the short run, the Open Up The West campaign largely failed to deliver results, partly because of the absence of steady oversight and demands for compliance from Beijing (Goodman 2004: 8-9). With time, however, its impact has been more marked, particularly in regions such as Xinjiang and Yunnan which were in desperate need of infrastructural development. Yet while the living standards and internal markets in both provinces have grown steadily since the early 2000s, the gap with China's richest coastal regions remains conspicuous. Moreover, due to geopolitical instabilities in several neighboring countries, both Yunnan and Xinjiang have seen their ambitions to become major hubs for cross-border trade and investments curbed.

To overcome those issues, and enhance China's economic and strategic influence across the region, current Chinese Communist Party (CCP) General Secretary Xi Jinping famously launched the "One Belt, One Road" strategy. As the following section will show through an analysis of two case studies in Yunnan and Xinjiang provinces, there are many continuities in the implementations of the Open Up The West campaign and OBOR. To be sure, a view "from the ground" is necessary to understand the effectiveness - or lack thereof - of such projects, and their implications for the projection of China's image across its national borders, and to shed light on the main discursive difference between those two major projects.

\footnotetext{
3 "Declaration of Shanghai Cooperation Organization", People's Daily, 15 June 2001: http:/en.people.cn/english/200106/15/eng20010615_72738.html.
} 


\section{OBOR in Yunnan and Xinjiang}

Yunnan and Xinjiang, despite their geographical, cultural, and historical differences, appear similar if analyzed from the perspective of China's development strategies for its borderlands. Xinjiang represents China's gateway to Central Asia, while Yunnan has been endorsed with a "bridgehead" (qiaotoubao) role to connect China and Southeast Asia (Zhou 2013). Both are land-locked provinces and share international borders with several countries: Russia, Kazakhstan, Kyrgyzstan, Tajikistan, Afghanistan and Pakistan in the case of Xinjiang; Myanmar, Laos, and Vietnam in the case of Yunnan. The ways the two provinces go about consolidating those roles are also strikingly similar. Among the most visible activities in this regard are two major fairs taking place in the provincial capitals: the China-Eurasia Expo in Urumqi, first launched in 2011, but whose roots go back to the Urumqi Foreign Economic Relations and Trade Fair held since 1992; and Kunming's China-South Asia Expo launched in 2013, now incorporating the China Kunming Import and Export Commodities Fair which had its 23rd anniversary in 2015. Similarities extend to smaller cases, most notably in the cities of Kashgar, western Xinjiang, and Tengchong, western Yunnan, both centers with a long history of cross-border trade, and today the recipients of large investments for the construction of Special Economic Zones and Border Trade Zones. Both cities, moreover, are central nodes of development within two major OBOR corridors: the China Pakistan Economic Corridor (CPEC) and the Bangladesh-China-India-Myanmar Economic Corridor (BCIM).

The strategic role of the two regions is also comparable, an element which, as argued in the previous section, represented one of the main drivers of the "Open Up The West" campaign, and that is certainly taken into consideration in the funding of many OBOR-led initiatives. Western Yunnan, on the one hand, has for several decades been one of the main routes through which drugs are smuggled into China, not to mention the CCP's long history of interference with Myanmar's civil wars along its border, from its backing of the Communist Party of Burma to its relations with various rebel armies active today, most notably the Kachin Independence Army (KIA) and the United Wa State Army (UWSA) (Lintner 1999). In Xinjiang, on the other hand, the main concern for Chinese authorities is represented by the fear of radical Islam infiltrating the region from neighboring Pakistan and Afghanistan, as well as Central Asia. While deadly incidents are regularly reported inside the region, Chinese officials have a long history of blaming "foreign influence" for 
those attacks, albeit often without providing any consistent proof of such interferences (Roberts 2012).

As a result of such tensions, in the case of the China-Pakistan border, news of generous investments in the China-Pakistan Economic Corridorwhich are currently projected at an astonishing figure of US\$ 46 billionare often accompanied by news of tightened border controls. ${ }^{4}$ This apparent contradiction was often at the center of my discussions with Pakistani traders in Xinjiang, in the course of my fieldwork. As part of the construction of the Kashgar Special Economic Zone (see below), many of them were offered office and retail space free of charge in order to foster cross-border exchanges and the local economy. Yet at the same time, many complained that they were often the subjects of humiliating inspections and questions at the border. As one trader from Aliabad put it: "Every time I cross the border I feel uncomfortable, it's like I'm a terrorist" (interview, June 2013). Encounters such as this seem to be occurring quite often, and not only within Xinjiang. In this sense, OBOR's ambiguous role as both a trade-promoting and security-enhancing initiative seems to generate the very possibility for such conflicts.

Finally, it is important to touch upon another issue connected to many OBOR-related projects: funding. In both the cases of Houqiao and Tashkurgan (see below), most investments are state-led, either by the local administration or through assistance programs that link up rich municipalities in eastern China with more remote areas such as Tengchong and Kashgar. While the official narrative is that, unlike traditional aid projects, OBOR-funded initiatives are meant to generate profits, it thus seems clear that at least in the initial stages, the state-through SOEs and financial institutions - will be leading the way, effectively providing the funding. To many of my interviewees in Houqiao and Tashkurgan, this was the source of a puzzling contradiction. While few denied the potential profitability of such projects, for many, the fact that the funding was coming from the state, was in itself evidence of the economic irrationality of the initiative. This situation led to the following paradox: local entrepreneurs seem unwilling to risk important sums in those projects, partly because they are reluctant to acknowledge chances for actual profit, but also because the current availability of state funding means that they do not necessarily need to come up with their own. A situation, I argue below, that might represent one of OBOR's main obstacles to success.

\footnotetext{
${ }^{4}$ Most recently in January 2017: "China's Xinjiang tightening border amid terrorist threat", Associated Press, 10 January 2017: https://www.yahoo.com/news/chinasxinjiang-tightening-border-amid-terrorist-threats-025540531.html.
} 


\section{Tengchong and Houqiao}

Tengchong is a county-level city governed by Baoshan prefecture, in western Yunnan, and shares a $151 \mathrm{~km}$ long border with Myanmar. Due to its specific geographical location along one of the main trading routes between China, India and South-East Asia, Tengchong (previously known as Tengyue) has a long history as an administrative, military and trade outpost (Fang 2010; Yin and Ma 1991). In the late nineteenth century, following its annexation of Myanmar - then known as Burma-Britain opened a customs post and consulate in Tengchong, taking advantage of the town's strategic position for trade. Following Burma's independence in 1948, and the establishment of the People's Republic of China (PRC) in 1949, several factors contributed to a significant decrease in cross-border economic relations. In particular, China's covert support for the Communist Party of Burma (CPB) seriously compromised the two countries' relations. Although local trade survived - and even flourished (Lintner 2011 [1990])—in communist-held areas, significant changes emerged only after the Burmese military coup in 1988 when the two countries began to strengthen their political and strategic ties. Since the 1990s, China and Myanmar's economic relations have eventually improved and cross-border trade has grown significantly, accounting now for about 70\% of Myanmar's total border trade (Kudo 2008; 2010).

With the normalization of relations, three official border crossings have been set up in Tengchong County alone: Houqiao (a national-level border port since 2004, known as the Kampaiti border crossing in Myanmar), Diantan (a provincial-level border port, locally often referred to using its Burmese name, Banwa Port) and Zizhi (the smallest, least busy, and most remote of the three, in the northernmost part of the county). Tengchong is also close to another important border post, Laiza, the current capital of the Kachin Independence Organization (KIO) bordering Yingjiang County in Dehong Prefecture.

As recently shown by anthropologist Zhou Yongming (2013), local authorities are putting a lot of effort in establishing Tengchong as crucial node - or, as in the official rhetoric, a "bridgehead"-for China-Myanmar trade. The flagship project, in this regard, is certainly the reconstruction of the Stillwell road to Myitkyina in Myanmar's Kachin state and to Assam state in India. The Stillwell road - also known as the Ledo road-was built by Chinese, Indian, and American forces during the Second World War as a supply route for Chiang Kai-Shek's troops fighting the Japanese army in Yunnan. Today, the new Stillwell Road runs from Tengchong to the Houqiao port, where a new trade center is currently under construction, 
while plans for its extension further into Myanmar and India are still under negotiation.

Plans for the development of cross-border trade in the area are, however, much more ambitious. Through the "One Belt, One Road" initiative, China is currently extending the newly-built BaoshanTengchong highway to Houqiao, and from there to Myitkyina, the capital of Myanmar's Kachin state. A major component of the Bangladesh-ChinaIndia-Myanmar (BCIM) Economic corridor, the long-term objective of this project is to tie those countries together through a network of infrastructures. With a similar goal, a new international terminal is currently under construction at Tengchong airport (inaugurated in 2009), with planned routes to Yangon, Mandalay, Calcutta, and Dhaka. Furthermore, a branch of the Kunming-Ruili railway will soon reach Tengchong, and from there it is planned to continue to Myitkyina and connect with the old, British-built railway in Kachin state. At the outskirts of Tengchong, moreover, the Baoshan city government is currently opening-up a new "Baoshan Houqiao Border Economic Cooperation Zone", which aims at profiting from the expected growth in cross-border trade. To Tengchong, which only in 2015 was elevated to the status of a county-level city (xianjishi), those various projects brought fast growth and large investments; as a result the small city is thriving with activities in one way or another connected to cross-border trade (Rippa and Yang 2017).

The story of the Houqiao border trade cooperation zone is in many ways parallel to that of the One Belt One Road Initiative. The company behind its construction, the "Tengchong Hong Yi Da Trading Company", was founded in September 2013 as an undertaking of public-private partnership - a legal form that is central to many OBOR-led initiatives. The company's stated aim is to work with the Tengchong and Baoshan governments to develop the Houqiao border trade cooperation zone into a major import-export hub, a goal towards which it has invested 320 million yuan (US\$46 million). The project comprises the construction of a socalled trade city (shangmao cheng) with wholesale market facilities, a shopping street and leisure areas for tourists.

At the time of my most recent visit, in September 2016, the main building of the trade city was almost completed. A representative of the company told me that around $40 \%$ of the space in the trade city has been sold - compared to $30 \%$ during my previous visit in January $2016 .{ }^{5}$ Most was sold to private companies from Yunnan engaged in exporting. The

${ }^{5}$ Interviews, Houqiao, January and September 2016. 
same representative laid out the plans for the future development of the area. While within the trade city, right next to the immigration facility, no other building will be constructed due to lack of space, a logistics center is currently under construction between the immigration facility and the actual border, less than $10 \mathrm{~km}$ away - a space that is referred to as "jingnei guanwai (within the border, outside customs)". Furthermore, the long-term plan is to create a larger border trade area that spans all the way from Houqiao to the border, following the model of Jiegao, in Ruili. Compared to Tengchong, Ruili has enjoyed a higher degree of openness and lower taxes since the late 1980s, thus becoming the main border crossing between Yunnan and Myanmar. The city's main port of entry at Jiegao had already been set up as a border trade zone in 1990, thus attracting early investments and businesses. Following the development of Jiegao, and the reconstruction of the Stilwell Road, it is clear that the goal of the Tengchong authorities is to re-claim the predominance in cross-border exchanges that Tengchong traditionally held, as opposed to Ruili's fairly recent success.

Yet as ambitions run high, several issues remain that might eventually jeopardize China's goals. In particular, what seems to worry Chinese investors and local traders alike is the fragile political situation in nearby Myanmar. Fighting between government forces and the KIA resumed in 2011 after seventeen years of relative peace following the 1994 ceasefire agreement. The election of a new government in 2015, and the halting of projects initiated by Chinese companies and with the support of the Burmese military have further exacerbated uncertainties among both Chinese officials and local businessmen, unwilling to make significant investments without specific assurances. Most dealers I interviewed in Tengchong agreed that the chaotic (luan) political situation in Myanmar was a major concern and a negative factor for their own businesses.

\section{Kashgar and Tashkurgan}

Kashgar, China's westernmost city, lies at the edge of the Taklamakan desert in the Xinjiang Uyghur Autonomous Region (XUAR), generally known simply as Xinjiang, in close proximity to the border crossings with Kyrgyzstan, Tajikistan, and Pakistan. Given this favorable position, Kashgar is today a core piece of Beijing's strategy to revive the legendary Silk Road, transforming it into a major hub of cross-border trade.

The most recent part of the plan was first laid out during a high level Xinjiang Work Conference, held in Beijing in late March 2010. On a general note, the Conference outlined a new approach for the Party's 
administration of Xinjiang, a particularly significant development given the Urumqi riots of the previous year (Millward 2009). The new approach abandoned the "stability above all else" formula that has defined the era of Wang Lequan, first as governor and then as Party Secretary of Xinjiang, and moved to one of "expedite development" (Shan and Weng 2013: 73). Furthermore, the Xinjiang Work Conference arranged a "pairing assistance" model according to which 19 affluent provinces and municipalities were "each required to help support the development of different areas in Xinjiang by providing human resources, technology, management and funds" (Shan and Weng 2013: 73). Within this scheme, for instance, Kashgar was paired with Shenzhen, China's most successful Special Economic Zone (SEZ). This new policy was eventually defined during a second conference in May 2010, significantly attended by then President $\mathrm{Hu}$ Jintao and Premier Wen Jiabao, as well as future President and Premier Xi Jinping and Li Keqiang. The conference once again highlighted that in order to solve Xinjiang's problems, it would be necessary to focus on economic development. The objective was then termed "leapfrog development", with the aim of eventually achieving "long term stability" in the region. As part of the program, Shan and Weng explained, "the 19 provinces and cities that joined the 'pairing assistance' program were required to grant $0.3 \%$ to $0.6 \%$ of their annual budget to Xinjiang every year" (2013: 75). Two other important measures resulted in a favorable tax system and the establishment of a new Special Economic Zone (SEZ) in Kashgar. As summarized by Cappelletti (2014: 17), the aim of the various development projects connected with the SEZ is "to cope with inequalities between the China's South-eastern regions and the North-western ones, and to make an effort to rebalance development disparities inside Xinjiang" - goals that reflect a stark continuity with the stated aims of the Open Up The West campaign.

Today, Kashgar is also a major node along one of OBOR's most ambitious projects: the China-Pakistan Economic Corridor (CPEC). The project comprises a $2,000 \mathrm{~km}$ route connecting the Pakistani port of Gwadar with Kashgar, but also rail links, special economic zones, dry ports and other infrastructures to be realized in Pakistan, mostly with the help of Chinese soft loans. Its purpose is to enhance cross-border trade, and possibly to transform the Karakoram Highway into the main artery for exchanges between South Asia, China and Central Asia. On the Chinese side, beside Kashgar, the small border town of Tashkurgan is receiving significant investment as part of the CPEC. Tashkurgan has a total population of about 40,000 (or over 60,000 if one were to include Chinese military personnel) and it represents the seat of the Tashkurgan Tajik 
Autonomous County, which borders Pakistan, Afghanistan and Tajikistan. One of China's remotest counties, placed in a high, barren plateau over 3,000 meters above sea level, Tashkurgan is undergoing impressive changes. June 2014, for instance, marked the beginning of the construction of a Border Trade Zone in the area. ${ }^{6}$ The Trade Zone, which will cost RMB100 million and cover an area of about 6.6 hectares, is meant to incorporate areas for trade, commerce, tourism, as well as hotels and restaurants. With the objective of providing 300 jobs for locals, the Trade Zone is projected to not only boost tourism and trade relations with nearby Tajikistan and Pakistan, but also to represent an important source of income for the local community.

Most recently, Xinhua, the official press agency of the People's Republic, reported that China has started construction work on a ChinaPakistan logistics complex in Tashkurgan. The project will include "an Internet service administration center, a cross-border e-commerce enterprise incubator, and a modern warehousing and logistics center", but also an exhibition center, hotels, and entertainment facilities. ${ }^{7}$ During a visit to Tashkurgan in the summer of 2016, I was once again able to appreciate the scale of the construction currently reshaping Tashkurgan, as well as the seriousness of Chinese investment in this remote county.

Long-lasting problems, however, remain beneath the shiny surface of multi-million RMB investments. Many Pakistani traders told me that on the Chinese side inspections are scrupulous and carried out with utmost scrutiny. Border guards are known to be very strict and careful, as they are looking for drugs (Swanström 2006: 116) and other illegal imports. Abdul Wakel, a major Pakistani carpet dealer in Kashgar, told me for instance that it can take days for a container of carpets to clear customs, as Chinese border guards unroll every single carpet checking for drugs. ${ }^{8}$ Similar stories, whether they concern dry fruit, handicrafts, beauty products, or other imports, are commonly shared among Pakistani traders in Xinjiang.

Beside drugs, another perceived threat for the Chinese government is, as already mentioned, represented by Islamist influences allegedly entering Xinjiang through the Karakoram Highway (Haider 2005). Besides the issue of border inspections targeting Pakistani traders, the Chinese authorities' focus on security has become a major obstacle for Uyghur

\footnotetext{
6 "Construction of border trade zone in Tashkurgan County (Kashgar, Xinjiang) officially begins", Xinhua, 23 June 2014: http://www.xj.xinhuanet.com/201406/23/c 1111268835.htm (Chinese).

7 "China-Pakistan logistics complex breaks ground in Xinjiang", Xinhua, 1 April 2016: http://news.xinhuanet.com/english/2016-04/01/c_135243654.htm.

${ }^{8}$ Interview, Kashgar, November 2012.
} 
mobility across regional and national frontiers. In the course of my research I came to realize that while in the 1990s Uyghur traders controlled an important part of trans-Karakoram trade, their role has shrunk to near-insignificance ever since, as it has become extremely difficult for them to obtain passports and visas necessary to travel (Rippa 2014). Paradoxically, then, as investments in cross-border infrastructures grew, from the Open Up The West campaign to OBOR, restrictions on local mobility, inspections and regulations increased simultaneously, in fact jeopardizing the two initiatives' stated goals.

To conclude, projects such as the Kashgar SEZ, the CPEC, as well as the BCIM and the development of the Houqiao border crossing have a history that precedes Xi Jinping's launch of the One Belt One Road. However, they have all been included in this new initiative. In the next two sections, I first show how those projects mark a significant continuity with previous attempts at developing the borderlands and enhancing crossborder trade, starting with the Open Up The West campaign. Yet despite those similarities, I then argue that the OBOR initiative reflects a distinctive change in vision, (dis)placing the borderlands from the peripheries to the center.

\section{Nodes of Development}

Recent attempts to "think ourselves beyond the nation" (Appadurai 1993: 411) have led scholars in the social sciences to address various cases where the direct rules of state seem to be suspended, or bent towards strictly market-driven neoliberal logics. One such attempt is Aihwa Ong's (2006) conceptualization of neoliberalism as exception and exceptions to neoliberalism. The former indicates an active neoliberal intervention in places where neoliberalism is not necessarily the main technology of governing. The concept addresses contexts "where market-driven calculations are being introduced in the management of population and the administration of special spaces" (Ong 2006: 3-4). Thus China's early strategy of respatializing development into Special Economic Zones administered according to different political conditions is an example of this particular approach. At the same time, exceptions to neoliberalism also play a role in political decisions and the management of certain spaces. State subsidies, for instance, can fall within this category, as well as a number of state-driven development projects. This section argues that Border Trade Zones and Special Economic Zones, such as those currently under development in Kashgar, Tashkurgan, Tengchong and Houqiao, 
represent interesting examples of how the logics of neoliberalism as exception and exceptions to neoliberalism overlap.

In order to make this argument, it is useful to begin with a brief analysis of how OBOR-related projects will be financed. Most of the financing will, in fact, most likely continue to come from bilateral mechanisms in the form of policy banks, including the Export-Import Bank of China and China Development Bank. Not all projects are, however, driven by commercial logic, as many analysts have recently pointed out. As reported by the Financial Times, for instance, "Chinese officials privately admit they expect to lose 80 per cent of their investment in Pakistan, 50 per cent in Myanmar and 30 per cent in central Asia". ${ }^{9}$ To be sure, CPEC projects are financed by low- or zero-interest concessional loans that include financing from China's Export-Import Bank and the Silk Road Fund. ${ }^{10}$ Those are very risky investments in an extremely unstable region, for a total of US\$46 billion. Here, as elsewhere, the apparent absence of any commercial logic is overshadowed by the strategic significance of the project: to reinforce long-standing China-Pakistan relations (Small 2015) and to follow through with the Party's belief in its ability to deliver security through economic development.

While low-interest concessional loans for risky projects mark clear exceptions to neoliberalism, the implementation of Special Economic Zones and Border Trade Zones all along China's borders - often as part of the same projects - represents an example of how neoliberalism can work as exception. The combination of those two approaches, I find, follows in the footsteps of previous programs, most importantly the Open Up The West campaign. As argued above, the main aims behind the Open Up The West campaign were as much economic as they were political, that is, to integrate and pacify the borderlands through state-driven economic development. Although much OBOR-related projects take place outside of China's borders, its objectives appear similar.

Similarities between the Open Up The West campaign and the Belt and Road Initiative extend to the language used by Chinese authorities to promote and implement various projects within such frameworks. Consider, for example, the statement on "Vision and Actions on Jointly Building Silk Road Economic Belt and 21st-Century Maritime Silk Road"

\footnotetext{
9 "How the Silk Road plans will be financed: Not all projects are driven by commercial logic", Financial Times, 10 May 2016:

https://www.ft.com/content/e83ced94-0bd8-11e6-9456-444ab5211a2f.

${ }^{10}$ Markey, Daniel, and James West. "Behind China's Gambit in Pakistan", Council on Foreign Relations, 12 May 2016: http://www.cfr.org/pakistan/behind-chinasgambit-pakistan/p37855\#.
} 
issued by the National Development and Reform Commission that sketches out the whole Belt and Road strategy. The text-which can also be found on the government website page dedicated to the One Belt One Road initiative - starts with a reference to the old Silk Road, recalling its spirit: "peace and cooperation, openness and inclusiveness, mutual learning and mutual benefit". The language that is recurrent throughout the text is that of inclusiveness, consultation, and even more importantly, mutual benefit, or "win-win cooperation". This sort of language is then scrupulously replicated in the context of each single project now part of OBOR, and indeed, in the cases of Kashgar, Tashkurgan, and Houqiao. Even the Hong Yi Da company corporate culture, as laid out on its website, follows this narrative of "win-win cooperation". ${ }^{11}$ This language is very similar to that used in previous projects comprised within the Open Up The West campaign, and can be found in both the Kunming Initiative text and the rhetoric of the Shanghai Cooperation Organization discussed above.

If we look at how things are developed "on the ground", moreover, the way OBOR is implemented in both Houqiao and Tashkurgan seems to follow in the footsteps of the Chinese developmentalist model based on "zones of exception" of various kinds-Special Economic Zones and Free Trade Zones in particular. Interestingly, this marks a clear contrast to the ways in which OBOR is often represented and imagined by both Chinese and non-Chinese authorities and media. In official pamphlets and news outlets, China's newest vision of global development is often accompanied by maps showing curvy arrows and lines linking up western China with Eastern Europe, its coastal provinces with India, west Africa, and northern Europe. Arrows fly through vast territories, producing an imaginary web of global connections-what is most striking about those maps is the absence of dots, of nodes, along those curvy arrows. There is very little sign, in other words, of recent Chinese efforts to build dry ports, logistics centers, border trade zones with storage facilities, and so on. The argument here is that, while the Belt and Road routes have not yet been fixed, development zones and special districts have, in fact, mushroomed all over the country. Moreover, many of those areas - such as Houqiao and Tashkurgan-are now incorporated into the OBOR vision as nodes of development central to the overall strategy. If, then, curvy arrows and large plans of trans-national connectivity are what make headlines, my argument is that the way this developmentalist model is actually enforced is through the establishment of specific nodes - or the absent dots on such

\footnotetext{
${ }^{11}$ The official website of the Hong Yi Da company: http://www.hyd99.cn/about/?166.html.
} 
maps. Notably, this is mostly the result of the efforts that local administrations put into the construction of logistics centers and bordertrade zones in anticipation of growing trade and interactions with neighboring countries. In this regard, in the ways OBOR is currently being implemented on the ground through various zones based on exceptions to neoliberalism - state funding and low-interest loans - the Belt and Road Initiative seems to follow in the footsteps of the Open Up The West campaign. The following section, however, will argue that despite remarkable similarities there is a major difference between the two initiatives.

\section{Centralizing Peripheries}

At the Kashgar Central \& South Asia Commodity Fair in 2013, an entire stand was dedicated to the new Kashgar Special Economic Zone. A poster highlighted Kashgar's strategic position for cross-border trade, describing it according to the slogan of "five ports (of entry) through eight countries, a road connecting Europe and Asia (wu kouan tong ba guo, yi lu lian ouya)". Kashgar, according to the same panel, was "China's great entryway to Central Asia, South Asia, the Middle East and even Europe", and particular emphasis was put on Kashgar's traditional role as a major hub along the Silk Road, its thriving bazaars, and geographical proximity to Central and South Asia. Various maps placed around the stand put Kashgar at the center, with various arrows departing from it towards all Central Asian countries as well as Pakistan, India, and various cities in central and eastern China.

Similar maps can be found in regard to Houqiao, inside a 160-page long project investment booklet published by Hong Yi Da company to introduce the new border trade zone. In such maps Houqiao is conveniently put at the center, with arrows and lines of various colors flying from there to nearby cities and countries, showing all the potential connections-from Kunming to Burma, Bangladesh and India. Both Kashgar and Houqiao, thus, are branded as future nodes of (economic) development because of their centrality-which is rendered as a precondition to economic cooperation and success.

Another point is worth noting here: those maps suggest that local administrations' attempts to attract funding rely on local histories of crossborder trade, or on a projection of a specific, strategically relevant imaginary network. In fact, unlike the Open Up The West campaign, nearly every Chinese province has a stake in the One Belt One Road Initiative, with local administrations actively competing for funding and 
projects. Anthropologist Zhou Yongming, in his analysis of Tengchong's attempt to become a crucial node within Yunnan's growing linkages with Southeast Asia, uses the expression "boxing out". What is interesting here, as elsewhere, is how this competition often takes the form of a specific kind of "spatial branding" based on a very selective interpretation of history. Thus, to quote Zhou Yongming for instance, "Yunnan has been quite successful in portraying itself as an important regional trade powerhouse by situating itself on two ancient trade routes: the Ancient Tea-Horse Road and the Southern Silk Road" (2013: 253). Tengchong, on the other hand, employs a more recent historical phase to make its claims: World War II and the Stilwell Road. Local authorities in Tengchong are thus actively - and selectively-emphasizing the history of World War II in the area in order to "re-brand" Tengchong as an important trading center and strategic post. Here, then, a link between history and current plans for future development emerges with references to heritage-making and tourism. Again, as Zhou points out:

Although the Stilwell Road was left to disintegrate after World War II, its marks on the physical landscape and in people's memories are still tangible. By refreshing a recent historical memory and rebuilding the old road, Tengchong is making a statement that the Stilwell Road is still the most viable route to connect China with India, thus positioning itself as the "bridgehead" on this route (Zhou 2013: 254).

Moving from this point, it is thus possible to generalize and argue that roads (their construction, uses, and the promises connected to them) and memories (of past connectivity and trade) play a crucial part in defining the role and position of a remote place in contemporary China. Against this background, Tengchong, Houqiao, Kashgar and Tashkurgan, are no longer "dead ends", but, as part of China's new Silk Road strategies, have become important nodes of connectivity - "bridgeheads" of modern crossborder exchange. Even in the imaginaries behind those projects, they are liberated from the margins, from the remote, peripheral borderlands, and rather placed at the center. Like the images at the Kashgar Central \& South Asia Commodity Fair and inside the Hong Yi Da company booklet, the margin becomes the center - or, to put it in a different way, the margins acquire a particular form of centrality. As nodes of connectivity, the main quality of those places lies precisely in their "centrality", in their ability to connect, or at least to project an image of connectivity. With the One Belt, One Road Initiative then, borderlands have been discursively "centralized", as new imaginaries of trans-national connectivity are created and reinforced, the very position of those seemingly remote, peripheral places is changing. 
Furthermore, a major difference between the Open Up The West campaign and the OBOR initiative lies in its scale. With OBOR, every province seems to have a stake in the initiative's investment drive, leading to the construction of logistics centers and border-trade zones in anticipation of growing trade and interactions with neighboring countries. This is a process in which competition between local administrations plays a very important role. The One Belt One Road is thus a less centralized effort than most might think, because much of the action occurs at local levels and at specific nodes such as those that I have described. Unlike the Open Up The West campaign, where the imaginary was still that of the center distributing to the underdeveloped and underperforming peripheries, with OBOR the margins, the peripheries, are reimagined as the center. This discursive shift might be, so far, the initiative's most important achievement.

By putting the borderlands at the center, at least discursively, the language within which OBOR-related projects are embedded, and which shares many similarities with previous initiatives such as the Open Up The West campaign, assumes a different nuance. This, I argue, is one of the reasons why the Chinese government has been quite successful at "branding" the Belt and Road initiative as mutually beneficial in various national contexts. This success can thus be seen not only in the pervasiveness of Belt and Road rhetoric within China, but mostly in the surprising lack of resistance and objections to the project within the countries that are supposedly involved in it. By centralizing the borderlands, in other words, Chinese authorities are able to include neighboring countries in its vision: the first step toward a concrete implementation of many OBOR projects.

\section{Conclusion}

It might seem rather surprising, given the breath and ambitions of the One Belt One Road initiative, that so far it has encountered very little resistance from either China's neighboring countries - those most affected by its vision - or from the West. To the contrary, the initiative has been largely welcomed and even encouraged by most Asian nations in clear need of infrastructures. Perhaps one reason for this success lies in the project's vagueness: for the time being we are offered maps with arrows and curvy lines connecting the extremes of Eurasia, yet there is still little knowledge of how those various projects will actually be implementedand financed - on the ground. 
Two points are worth noting here. First, there is a significant power in this vagueness: as long as plans remain uncertain, and arrows are large and curvy enough to sweep across vast territories, policy-makers can maintain the excitement of the initiative without having to deal with the nitty-gritty of local policies and the discontent of those who might feel left out. Curvy arrow maps are powerful, in other words, not despite their vagueness, but precisely because of it. It is this vagueness that can trigger expectations, and that ultimately makes the One Belt One Road Initiative so pervasive, and at least at the level of the imaginary, already successful. Secondly, as this paper has shown, the "vision" behind OBOR is already having a significant impact on how projects are implemented and borderlands reimagined in today's China. Despite the fact that OBOR employs the same language as previous initiatives, the discursive shift within which it is embedded makes it a much more successful tool in China's attempts to pursue its long-term interests.

To conclude, trying to weave together some of the issues that I have briefly touched upon, Xi Jinping's Belt and Road Initiative certainly represents a more focused and better coordinated effort to expand China's economic influence overseas than anything that has been previously envisioned by Chinese authorities. It is not, however, an operational blueprint: rather, One Belt One Road is more of a sweeping vision, which brings together new ideas (Xi's China Dream), new policies (peripheral diplomacy), and institutions (AIIB). I have argued that in order to be powerful and successful as a vision it has to remain vague. The question with which I conclude, then, is whether this vagueness will remain the One Belt One Road's main strength, or if it will, at some point, turn into a haunting weakness.

\section{References}

Appadurai, A. (1993). Patriotism and its Futures. Public Culture 5(3): 411429.

Bequelin, N. (2004). Staged Development in Xinjiang. The China Quarterly 178 (2): 358-378.

Callahan, W.A. (2016). China's "Asia Dream": The Belt Road Initiative and the new regional order. Asian Journal of Contemporary Politics 1(3): 1-18.

Cappelletti, A. (2014). Social Change in Kashgar from a Cultural and Religious Oasis along the Silk Road to the "Dubai of Central Asia". In Han, S., and P. Santangelo (Edited by). Proceedings of the "Social Changes in China" Academic Workshop. Ariccia: ARACNE, 13-23. 
Clarke, M. (2008). China's Integration of Xinjiang with Central Asia: Securing a "Silk Road" to Great Power Status? China and Eurasia Forum Quarterly 6(2): 89-111

Fang, I. (2010). “'Talking' Landscape: The Culture Dynamics of Rushang (Confucian Entrepreneurs) in a Peripheral Migrant Hometown in Yunnan". The Asia Pacific Journal of Anthropology 11(2): 191-204.

Goodman, D.S. (2004). The Campaign to "Open Up The West": National, Provincial-level and Local Perspectives. Cambridge: Cambridge University Press.

Haider, Z. (2005). Sino-Pakistan Relations and Xinjiang's Uighurs: Politics, Trade, and Islam along the Karakoram Highway. Asia Survey 45(4): 522-545.

Johnson, C.K. (2016). President Xi Jinping's "Belt and Road" Initiative. Center for Strategic \& International Studies.

Kudo, T. (2008). Myanmar's economic relations with China: who benefits and who pays? In: Skidmore M., and T. Wilson (eds). Dictatorship, Disorder and Decline in Myanmar. The Australian National University E Press, pp. 87-109.

Kudo, T. (2010). Myanmar's Border Trade with China: Situation, Challenge and Prospects. In: Mitsuhiro Kagami (Edited by), Japan and Korea with the Mekong River Basin Countries. BRC Research Report No.3, Bangkok Research Center, IDE-JETRO, Bangkok, Thailand.

Lai, H. (2002). China's Western Development Program: Its Rationale, Implementation, and Prospects. Modern China 28(4): 432-466.

Laruelle, M., and S.Peyrouse. (2012). The Chinese Question in Central Asia: Domestic Order, Social Change, and the Chinese Factor. London: Hurst.

Lintner, B. (1999). Burma in Revolt: Opium and Insurgency Since 1948. Chiang Mai: Silkworm Books.

-. (2011 [1990]). Land of Jade: A Journey from Indian through Northern Burma to China. Bangkok: Orchid Press.

Millward, J. (2009). Introduction: Does the 2009 Urumqi violence mark a turning point? Central Asian Survey 28(4): 347-360.

Ong, A. (2006). Neoliberalism as Exception: Mutations in Citizenship and Sovereignty. Durham and London: Duke University Press.

Rippa, A. (2014). From Uyghurs to Kashgaris (and back?): Migration and Cross-border Interactions between Xinjiang and Pakistan. Crossroads Asia Working Paper Series, No. 23.

Rippa, A.; and Y. Yang. 2017. The Amber Road: Cross-Border Trade and the Regulation of the Burmite Market in Tengchong, Yunnan. TRaNS: Trans-Regional and -National Studies of Southeast Asia 5(2): 243-267. 
Roberts, S.R. (2012). Imaginary Terrorism? The Global War on Terror and the Narrative of the Uyghur Terrorist Threat. Ponars Eurasia Working Paper.

http://www.gwu.edu/ ieresgwu/assets/docs/ponars/RobertsWP.pdf. [Accessed December 2014].

Shan, W., and C. Weng. (2013). China's "New Deal" in Xinjiang and its Challenges. In Wang, G., and Y. Zheng (Edited by). China: Development and Governance. Singapore: World Scientific Publishing.

Shichor, Y. (2008). China's Central Asian Strategy and the Xinjiang Connection: Predicaments and Medicaments in a Contemporary Perspective. China and Eurasia Forum Quarterly 6(2): 55-73.

Small, A. (2015). The China-Pakistan Axis: Asia's New Geopolitics. London: Hurst \& Company.

Yan, J. (2001). Zhongguoxibu da kaifa de zhanlüeyuduice (China’s Great Opening of the West strategy and ways to deal with it). Beijing: Kexuechubanshe.

Yin, W., Ma, Z. (edited by). (1991). Tengchongwenshiziliaoxuanji. Tengchong: Tengchong County CPPCC literature and history division committee.

Zhou, Y. (2013). Branding Tengchong: Globalization, Road Building, and Spatial Reconfigurations in Yunnan, Southwest China. In: Blumenfield, T. and H. Silverman (Edited by) Cultural Heritage. Politics in China. New York: Springer, 247-260. 
